\title{
ECOTOXICOLOGICAL ASSESSMENT OF POLLUTANTS MIGRATION IN ECOSYSTEM
}

\author{
Ryzhenko N.O., Pozhylenko A.S., Kozak L.V., Nesterov D.Yu., Frolova T.M. \\ State Ecological Academy of Post-Graduate Education and Management \\ Mytropolyta Lypkivskogo str., 35, 03135, Kyiv \\ alsko2011@ukr.net
}

\begin{abstract}
One of the key ecotoxicological indexes at the pollutants' danger assessment is the migration in the ecosystem. As a rule, plant up-taking is characterized as the main migration channels in the "soil-plant" system. Investigation of contaminants up-take by plant in polluted soil is important because it gives the possibility to compare toxicants dangerous as well as to predict their translocation and harmful influence on plant. $\mathrm{T}_{50}$ index (half-life period) also highlights the pollutants behavior in soil because it characterizes their persistent in environment. Pollutants migration rate depends on their properties, doze and environment peculiarities. Key words: pollutants, migration, contamination, ecotoxicalogical assessment.
\end{abstract}

Екотоксикологічна оцінка міграції полютантів в екосистемі. Риженко Н.О., Пожиленко А.С., Козак Л.В., Нестеров Д.Ю., Фролова Т.М. Екотоксикологічна оцінка небезпечності полютантів включає один із ключових індексів показник міграції в екосистемі. Одним з основних міграційних каналів у системі «грунт - рослина» $є$ біоакумуляція фітокомпонентом. Здатність рослин до поглинання $є$ вкрай важливим фактором у вивченні токсичності полютантів, оскільки цей показник дає змогу не лише порівняти їх небезпеку, а й прогнозувати транслокацію та реакцію рослинного організму на їх дію. Показник $\mathrm{T}_{50}$ (період напіввиведення) також розкриває поведінку полютантів у грунті, оскільки характеризує їх стійкість у довкіллі. Інтенсивність міграції полютантів в екосистемі залежить від їх властивостей, дози та особливостей середовища. Ключові слова: полютанти, міграція, забруднення, екотоксикологічна оцінка.

Экотоксикологическая оценка миграции поллютантов в экосистеме. Рыженко Н.О., Пожиленко А.С., Козак Л.В., Нестеров Д.Ю., Фролова Т.М. Экотоксикологическая оценка опасности поллютантов включает один из ключевых индексов - показатель миграции в экосистеме. Одним из основных миграционных каналов в системе «почва - растение» является биоаккумуляция фитокомпонентом. Способность растений к поглощению является важным фактором при изучении токсичности поллютантов, поскольку этот показатель позволяет не только сравнивать их опасность, но и прогнозировать транслокацию и реакцию растительного организма на их действие. Показатель $\mathrm{T}_{50}$ (период полувыведения) также раскрывает поведение поллютантов в почве, поскольку характеризует их персистетность в окружающей среде. Интенсивность миграции поллютантов зависит от их свойств, дозы и особенностей среды. Ключевые слова: поллютанты, миграция, загрязнение, экотоксикологическая оценка.

Formulation of the problem. For 2 million years, humanity was in the homeostasis with the biosphere. Homeostasis was supported by the animist outlook [1]. This strategy of life ended when humankind learned to exploit natural resources. The result of thishuman occupation strategy for Nature is the boundary of the total ecological catastropheafter which biosphere can be transforms into a technosphere in one jump [2;3].Today, the loss of productive land compared with the average annual rate of 10 thousand years of civilization has increased by 30 times. Dehumidification of soils has increased by 24 times, while the average yield increase over the past 50 years was only $30 \%$. There is the risk of disappearance for more than 26000 species of plants and animals in the World, and for near 1000 species in Ukraine $[1 ; 3 ; 4]$. The increasing of general biosphere ecological crises caused, of course, by an anthropogenic factor [5]. The main role in the balanced development in biosphere plays, as is known, the regularity of the individuals' number in the trophic chain $[3 ; 6]$. This is a self-regulating system of "producers - consuments - reductants", and the number of individuals varies annually within a certain average [5]. Thus, a balanced circulation of matter and, consequently, a component and territorial ecological balance are provided [2; 5]. Plants are the source of the formation of phytomass and play a leading role in the presence of the complete conditions for healthy human functioning. Plants are not only oxygen source in biosphere, but also are producent in the trophic chains (in which human is a final link). Moreover, plants play an important role in the soil-forming process and in the soil buffer capacity. Additionally, plants are filtered biosphere as a buffer, which accumulates most of pollutants. Plants play a main role in ensuring a balanced circulation of matter and, creating the thin membrane of life. The general trend and function of this membrane of life is biodiversity development, balancing of substances and energy in the environment in accordance with its energy-accumulating, geochemical, stabilizing and informational planetary roles. Plants, accumulating the energy of the Sun and producing biomass, ensures the functioning of the biosphere and its 
permanent composition as well as the territorial and component dynamic equilibrium in ecosystem $[3 ; 5 ; 7]$.

From the main function of ecosystems (the ability to accumulate energy in organic matter, in other words, productivity), from its size and dynamics completely depends the life of all existing on Earth (Fig. 1).

In the context of any type of contamination by pollutants, the study of their migration is particularly important, since bioaccumulation of toxicants causes quantitative (decrease in productivity) and qualitative changes (increase in the content of pollutants in the plant and reduction of the required substances for the plant itself and consumpts). In this connection, the phytotoxico- logical scientific direction, which studies toxic effects on plants caused by any origin pollutants, in particular, for the population level, is extremely relevant. To the indicator processes of the global ecological crisis, scientists include geochemical pollution of air, water and soil, geochemical poisoning of biota as a result of metallization, chemotoxication, radiootoxication, as well as activation of processes of technogenesis and violation of biogeochemical cycles in the biosphere [1].

Topicality. Ecotoxicological assessment of the pollutants danger includes one of the key indices - the intensity of migration in the ecosystem. It is known, that migration occurs in different vectors with different

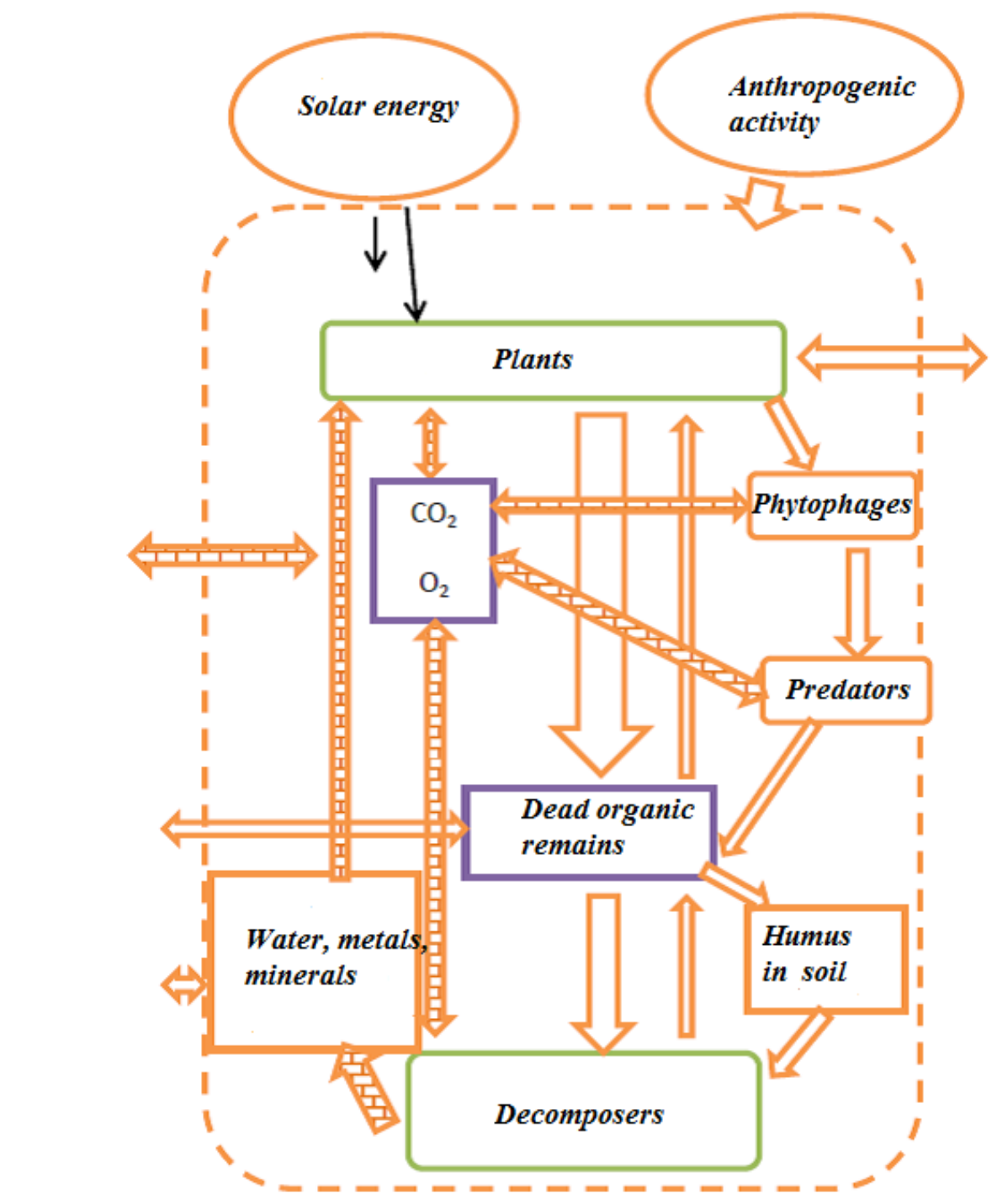

The boundary of the ecosystem

Traffic channels of organic matter

Channels of mobility of metals and other minerals

Figure. 1. Scheme of structural and functional organization of ecosystems (by Elenberg) [7] 
characteristics in environments. Today migration of substances is increasingly becoming anthropogenic rice. In this connection, the list of elements in the geochemical anomalies, which are formed as a result of the violation in the biogeochemical cycles, at a certain stage of society development, is comparatively constant.

According to the opinion of many scientists, the typical composition of the geochemical man-made anomalies today is $\mathrm{Pb}, \mathrm{Cu}, \mathrm{Zn}, \mathrm{Mo}, \mathrm{Ba}, \mathrm{Co}, \mathrm{Mn}, \mathrm{Fe}, \mathrm{Ni}, \mathrm{As}$, as their accumulation in the environment continues at high rates $[8 ; 9]$. In the initial period of the formation of the industrial development of society, large manmade anomalies were formed by a significant number (more than 10) number of chemical elements. The elements with the highest contrast (with higher relative content) are called priority pollutants. At the next stage of development of scientific and technological progress, the association of the composition of the geochemical anomaly will expand considerably. According to of the ecological postulate (formulated by Alekseyenko), associations of chemical elements, forming large manmade geochemical anomalies, are determined mainly by the level of development of science and technology during the period of pollution [5]. Gradually, the list of man-made sources of toxic metals in the ecosystem is expanding (Fig. 2).

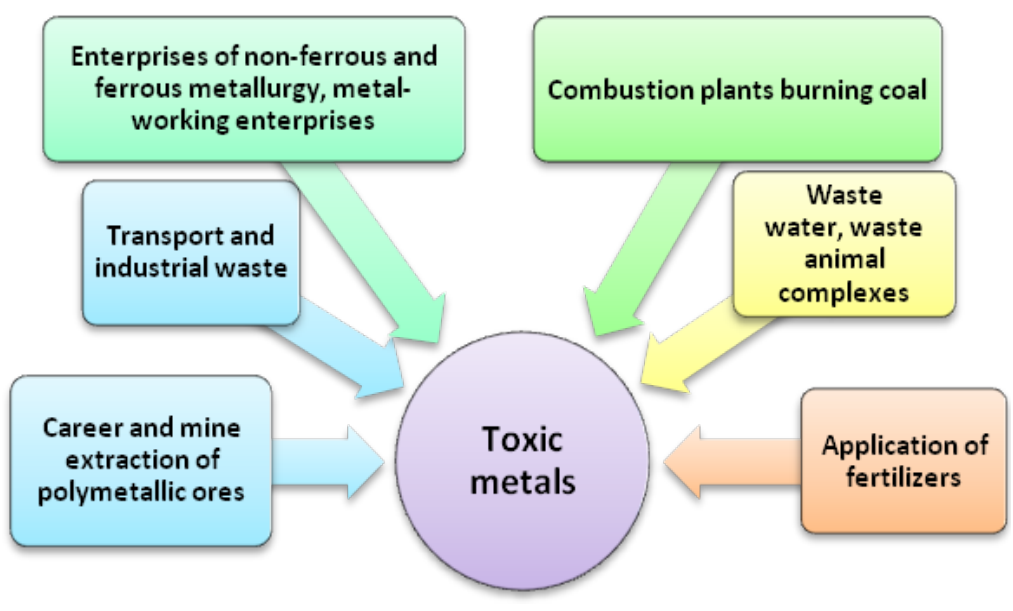

Figure 2. The main sources of man-made toxic metals in ecosystems (by Honcharuk et al., 2017) [10]

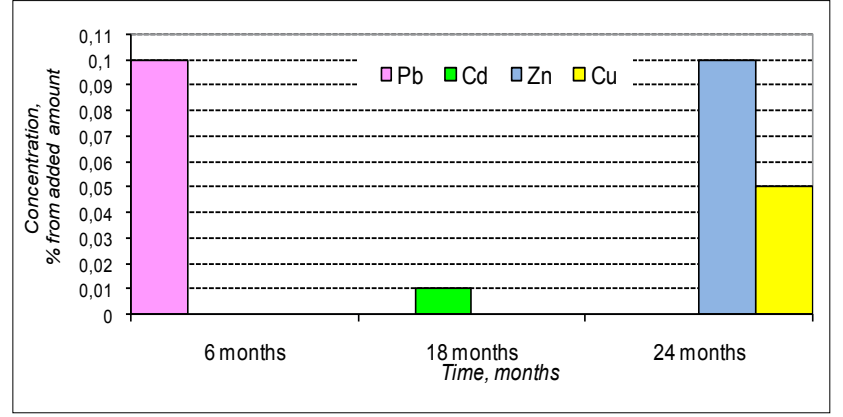

a) polluted chernozem soil
Today, special attention to migration assessment is also given to such pollutants as persistent organic pollutants (POPs) which, according to the Stockholm Convention, are substances that have toxic properties, exhibit resistance to decomposition, are characterized by bioaccumulation and are the object of trans boundary transport by air, water and migratory species, and also sediment at a great distance from the source of their release, accumulate in the ecosystems of land and aquatic ecosystems [11]. Typically, POPs are of anthropogenic origin, and their list of Annexes A and B of the Stockholm Convention includes pesticides: Aldrin, Chlorodan, Diederine, Endrin, Heptachlor, Mirex, Toxaphene, Dichlorodiphenyl trichloromethylmethane (DDT), which are now or are not used, or are restricted to application in agriculture, but often make up the hazardous waste [11]. However, the prediction of the behavior in the environment of any toxicants requires a thorough study and the establishment of the limits and specifics of their migration. Toxicants' migration prediction will allow controlling the quality of the environment more efficiently.

Presenting main material. Most of the toxicants are concentrated in the upper layers of the soil at the pollution. A small part of the toxicants reaches the lower ground horizons (Fig. 3). Therefore, the half-life $\left(T_{50}\right)$ of toxicants in the $0-40 \mathrm{~cm}$ layer of soil is usually determined. This indicator of persistent toxicity plays a very important role in assessing its hazard, since bioaccumulation of substances occurs mostly in the roots of the soil layer. Half-life period is calculated according to the following equation:

$$
T_{50}=\frac{0,693}{k},
$$

where $k$ is the constant of toxicants' dissipation which calculated with the help of exponential equation [12].

In the ecosystems pesticides are destructed by different factors: biotic (living organisms) and abiotic (temperature, $\mathrm{pH}$ of medium, sun isolation). Speed of the pesticide destruction depends on physical

Figure 3. The term of appearance of the toxic metals' moving forms in the 80-100 cm layer 
Half-life period and dissipation constants of some substances in $0-20 \mathrm{~cm}$ soil layer, $P_{0.05}[12 ; 13]$

\begin{tabular}{|c|c|c|}
\hline Substances & $\boldsymbol{\kappa}$ & $\mathbf{T}_{\mathbf{5 0}}$ \\
\hline Dursban (chlorpyryphose) & 0,07 & 9,9 day $^{-1}$ \\
\hline Stomp (Pentoxalin) & 0,23 & 3,0 day $^{-1}$ \\
\hline Ozadiksil (Sandophan) & 0,34 & 2,0 day $^{-1}$ \\
\hline Bentazon (Bazagran) & 0,12 & 5,8 day $^{-1}$ \\
\hline $\mathrm{Pb}$ & 0,6381 & 0,96 year $^{-1}$ \\
\hline $\mathrm{Cd}$ & 0,6987 & 0,87 year $^{-1}$ \\
\hline $\mathrm{Zn}$ & 0,9116 & 0,65 year $^{-1}$ \\
\hline $\mathrm{Cu}$ & 1,2158 & 0,53 year $^{-1}$ \\
\hline
\end{tabular}

and chemical properties of substances (for example, polarity) and, of course, on environmental conditions. Polar pesticides are destructed in soil more intensive than non-polar pesticides in 2-3 times. This regularity was highlighted in previous papers. The destruction of pesticides substance is described by dissipation constant (k) (table 1).

Plant up-taking and vertical migration in soil profile belongs to principal migration paths (makes up more than $10 \%$ of the contributed amounts) in the case of toxic metals ecosystem pollution. Horizontal migration in soil, ruderal species up-taking, and deposition to immobile form in soil belongs to minor migration paths. Evaporation belongs to inessential migration paths and

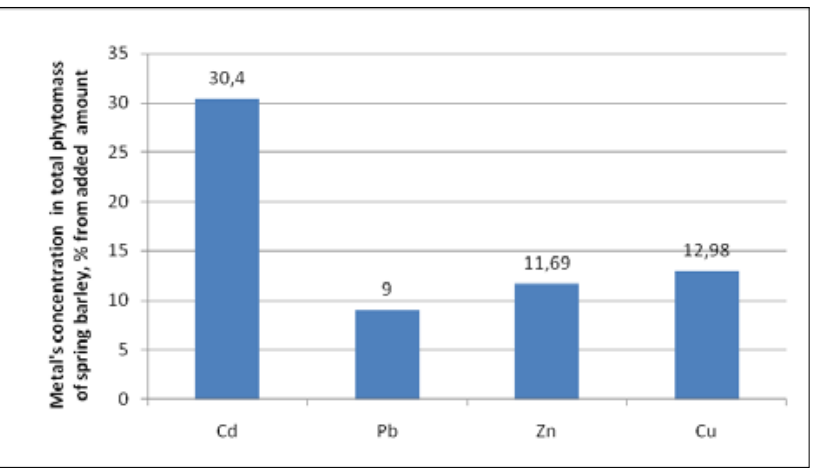

Figure 4. The plant up-taking ability of spring barley (in an experiment with the metals adding in black soil)
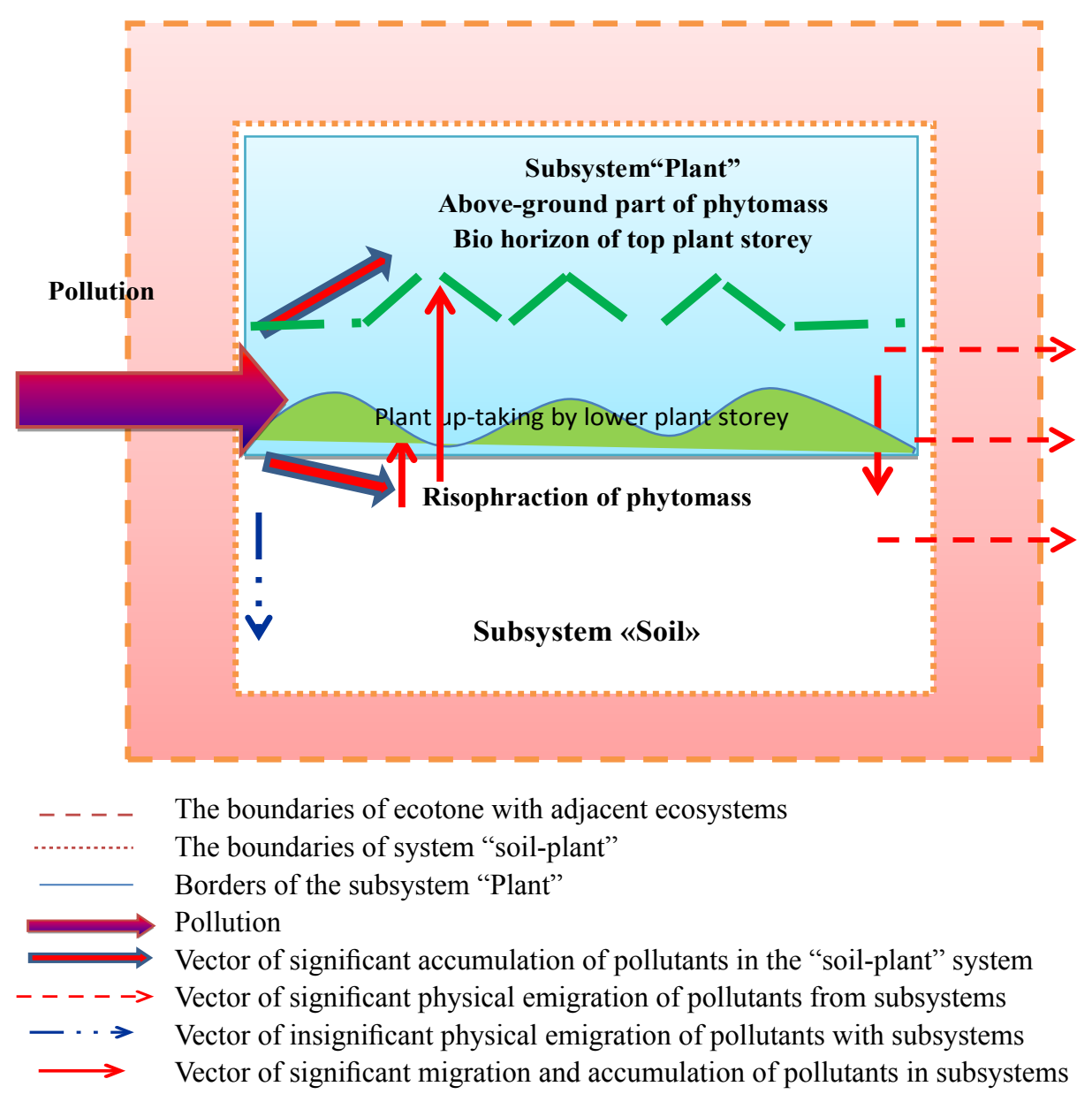

Figure 5. Pollutants' migration in ecosystem 
makes up less than $0.001 \%$ of the initial quantity. Most of the metals as well as POPs usually are located in the top layers of soil during the first three years after pollutant adding in soil [12].

The significance of the bioaccumulation intensity in ecosystems cannot be overestimated, since precisely the toxicants plants up-taking is often a major migration channel. Thus, the coefficients of bio-accumulation of metals can range from 0,2 to 14 depending on the metal and the species (or culture) of plants $[14 ; 15]$. In experiments with the metals artificial adding, depending on the metal, the bioaccumulation ability of some crops is up to $30 \%$ of the initial amount of metal added into the soil (Fig. 4). The bioaccumulation ability of the plant is influenced by a number of factors, including plant physiology, type and level of contamination, geochemical capacity of the soil, etc. In addition, the ability of plants bioaccumulation is one of the most important indices in the study of the toxicity of the pollutants, because it not only allows to compare the toxicity of the pollutants, but also to provide a prediction of translocation, bioaccumulation of the pollutants and the reaction of the plant organism to their effect. The rate of plant up-take of the metals and organic substances depends on the physical and chemical properties of the toxicant, soil properties (organic matter content, and other agro-physical properties) and the crops bioaccumulation capacity. Bioaccumulation capacity and the pollutants toxic effects are characterized by the plant up-take index [14].

According to the frequency, contamination can be systemic (with different frequency and duration), or impacted (one-time alarms with different quantitative effect). The main biogeochemical principles such as Main Biogeochemical Principle (formulated by Goldschmitt), and the Principle of Biogenic Migration of Atoms (formulated by Vernadsky) gave the possibility to distinguish a few essential paths of toxicants migration. There are physical migration and plant up-taking (Fig. 5). Physical migration of pollutants depends on the structural and physical properties of the "soil-plant" system, which characterizes the ability of the ecosystems to be resistant (during possibly maximum period without pollutants adding into biogeochemical processes). The mechanism of activation of the bioaccumulative capacity of the ecosystem depends on the phytocomponent, because the phytocomponent, as a rule, plays a key role in the whole bioproductivity in the ecosystem and has environment generating function [5]. In this regard, the degree of biogeochemical active accumulation of contaminants determines the stability and balanced development of the ecosystem, and also characterizes the level of toxicity of toxicants to the ecosystem.

Conclusions. Migration of pollutants in the ecosystem is an obligatory indicator that allows assessing the toxicity of substances. The half-life of pollutants $\left(\mathrm{T}_{50}\right)$ as important index of pollutant toxicity characterizes the persistent as well as predicts contamination levels in the components of the ecosystem. The rate of reduction of toxicants contamination depends on the physical and chemical properties of the substances and the characteristics of the soil ( $\mathrm{pH}$, granulometric composition, organic matter, plants canopy, etc.).

The main significant way of migration of pollutants in the ecosystem is bioaccumulation, which is influenced by a number of factors, such as physiological features of plants, type and level of contamination, geochemical capacity of the soil, etc. Bioaccumulation is an important index in the study of toxicity of pollutants, since this indicator not only allows for comparison of toxicity, but also predicts their hazard for biota.

\section{References}

1. Zubakov V. Aspects of the ecogeosophical paradigm. Bulletin of the National Academy of Sciences of Ukraine. 2003. Vol. 1. P. 30-38.

2. Shelyagh-Sosonko Y. Biodiversity: the concept, culture and role of science. Ukrainian Botanical Journal. 2008. Vol. 65(1). P. 3-25.

3. Sytnyk K. Noosfera: myths and reality. Bulletin of the National Academy of Sciences of Ukraine. 2003. Vol. 2. P. 51-62.

4. How to restore the ecosystem balance? / Y. Shelyagh-Sosonko, Y. Movchan, L. Vakarenko, D. Dubina. Bulletin of the National Academy of Sciences of Ukraine. 2002. Vol. 10. P. 5-14.

5. Reymers N. Ecology (theories, laws, rules, principles and hypotheses). Moscow : Russia young, 1994. 367 p.

6. Dedyu I. Ecological Encyclopedic Dictionary. Chisinau : Heads. Ed. ITU, 1990. 408 p.

7. Ellenberg H. Ziele und Stand der Okosystemforschung. Berlin : Springer-Verlag, 1973. 31 S.

8. Heavy metals in soils. Trace elements and Metalloids in Soils and their Bioavailability / ed. B. Alloway. London, UK : Springer, 2010. $235 \mathrm{p}$.

9. Prokhorova N., Matveev N. Heavy metals in soils and plants in the conditions of technogenesis. Vestnik SamGU. 1996. Special issue. P. $125-147$.

10. Honcharuk E., Zagoskina N. Heavy metals: Entrance, toxicity and protective mechanisms of plants (by the example of cadmium ions). Bulletin of Kharkiv National Agrarian University. Series "Biology”. 2017. Vol. 1(40). P. 35-49.

11. Stockholm Convention on Persistent Organic Pollutants (ukr/rus), the Law of Ukraine on Ratification of the Stockholm Convention on Persistent Organic Pollutants. URL: https://zakon.rada.gov.ua/laws/show/995_a07.

12. Ryzhenko N., Kavetsky V. The kinetics of the migration of Lead, Cadmium, Cooper and Zinc in the conditions of turf-podzol Sandy loam and chernozem soil. Polish Journal of Soil Science. 2013. Vol. XLVI. № 2. P. 125-129.

13. Kavetsky V., Ryzhenko N. Physical and Chemical Criteria for Pesticides Determination and Risk Assessment in Ecosystem. Polish J. Chem. 2008. Vol. 82. P. 361-369.

14. Ryzhenko N., Kavetsky S., Kavetsky V. Heavy Metals (Cd, Pb, Zn, And Cu) Uptake By Spring Barley In Polluted Soils. Polish Journal of Soil Science. 2015. Vol. XLVIII. № 1. P. 111-129.

15. Bondar O., Ryzhenko N. Phytotoxicological classification of toxic metals according to the intensity of their bioaccumulation in the conditions of green parks zones of Kyiv. Agroecological journal. 2017. Vol. 3. P. 32-40. 